Document downloaded from:

http://hdl.handle.net/10251/78467

This paper must be cited as:

San Bautista Primo, A.; López Galarza, SV.; Maroto Borrego, JV.; Pascual España, B. (2009). Influence of anion proportions in the nutrient solution on tipburn incidente in strawberry plants in soilless cultivation. Acta Horticulturae. 842(2):999-1008. doi:10.17660/ActaHortic.2009.842.222.

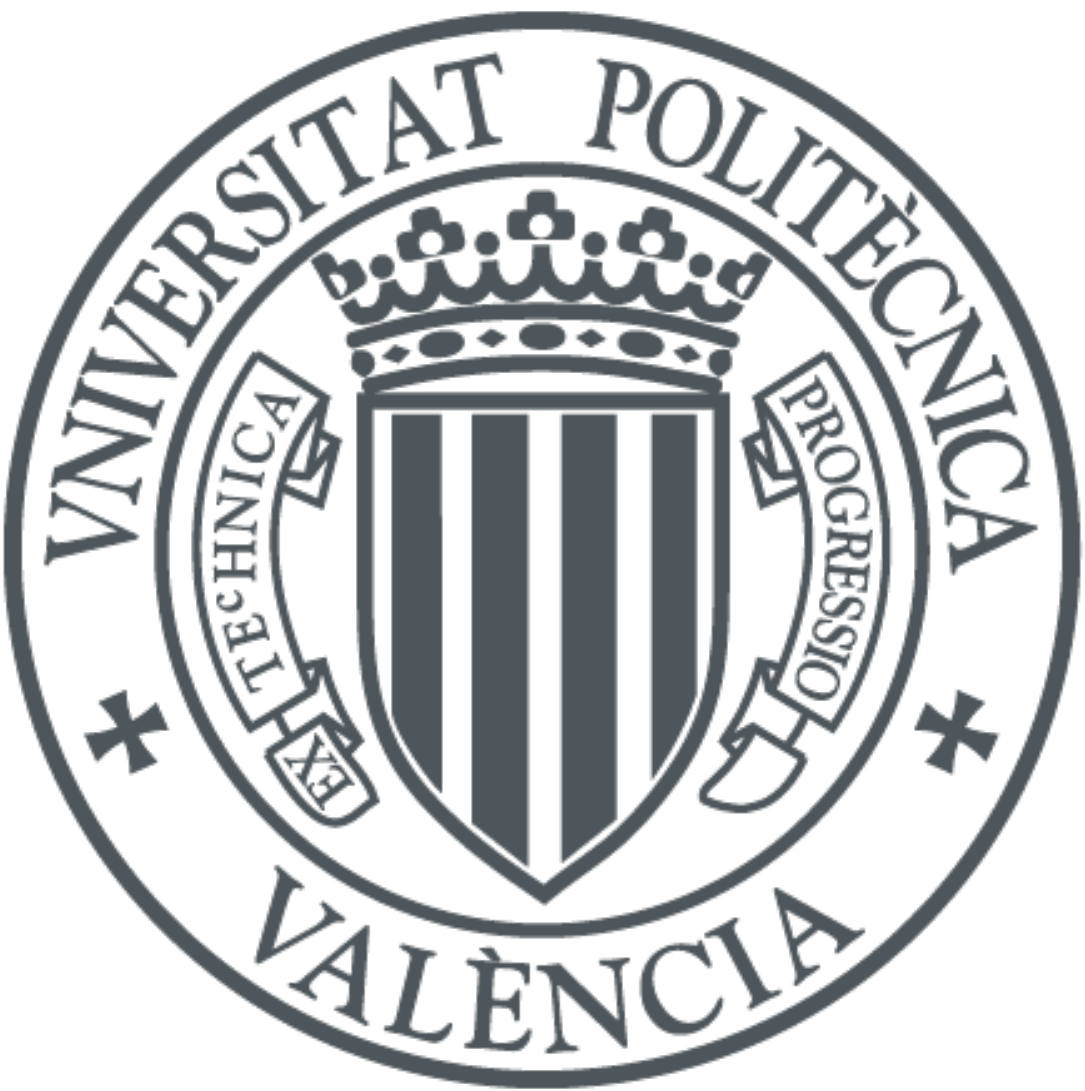

The final publication is available at

http://dx.doi.org/10.17660/ActaHortic.2009.842.222

Copyright International Society for Horticultural Science (ISHS)

Additional Information 


\title{
Influence of Anion Proportions in the Nutrient Solution on Tipburn Incidence in Strawberry Plants in Soilless Cultivation
}

\author{
A. San Bautista, S. López-Galarza, Á. Martínez, J.V. Maroto and B. Pascual \\ Departamento de Producción Vegetal, ETSIA \\ Universidad Politécnica de Valencia \\ Camino de Vera s/n, 46022 Valencia \\ Spain
}

Keywords: soilless, disorder, quality, yield, nutrition

\begin{abstract}
Tipburn incidence was evaluated in 'Camarosa' and 'Candonga' strawberry plants grown in perlite by varying the anion proportions in the nutrient solution during 2005-2006 under greenhouse. Six nutrient solutions with different proportions of $\mathrm{NO}_{3}^{-}, \mathrm{PO}_{4} \mathrm{H}^{2-}$ and $\mathrm{SO}_{4}{ }^{2-}$ were studied, maintaining constant both cation proportions and the total ionic concentration $\left(30.2 \mathrm{meq}^{-1}\right)$. Concentrations of these anions varied from 9.0 to $12.8,0.9$ to 4.7 , and 0.75 to $2.65 \mathrm{mM} \mathrm{L}^{-1}$, respectively. Interactions between cultivars and solutions were not significant for any of the parameters studied. The anion proportions had no influence on yield parameters. Both the percentage of leaves with tipburn and tipburn severity per leaf were the highest with intermediate levels of sulphates and phosphates and low levels of nitrates. 'Candonga' not only produced the highest yield and fruit weight, but also the lowest tipburn incidence.
\end{abstract}

\section{INTRODUCTION}

Tipburn is the main abiotic disorder of strawberry, characterized by necrotic tissues in the emergent leaves, sometimes in sepals. Tipburn is considered to be related with calcium deficiency on strawberry tissues (Mason and Guttridge, 1974), usually resulting from its reduced transport to young leaves more than by calcium availability (Mason and Guttridge, 1975). In previous experiments we have studied the interactions among $\mathrm{Ca}, \mathrm{K}$ and $\mathrm{Mg}$, as a balance in the nutrient solutions, and their influence on tipburn appearance in strawberry plants (López-Galarza et al., 2003). In the present work, we wanted to study the effect of different macroanion $\left(\mathrm{NO}_{3}{ }^{-}, \mathrm{H}_{2} \mathrm{PO}_{4}{ }^{-}\right.$and $\left.\mathrm{SO}_{4}{ }^{2-}\right)$ proportions in the nutrient solution on tipburn appearance in strawberry plants, which would affect plant growth and thus its indirect effect on tipburn, when maintaining balanced proportion of other anions like phosphorus and sulphates. On the other hand, these anions have also been related to tipburn appearance directly or indirectly by affecting calcium availability.

\section{MATERIAL AND METHODS}

The experiment was carried out during the 2005-2006 season at Valencia, Spain. Plug plants of 'Camarosa' and 'Candonga' raised at a high altitude in, Ademuz (Valencia) $\left(40.02^{\circ} \mathrm{N}, 1.25^{\circ} \mathrm{W}, 802 \mathrm{~m}\right)$ were planted in a Venlo-type glasshouse on 14 October 2005. Plants were arranged in a completely randomized design of three replications of 16 plants and were grown in $40 \mathrm{~L}$ perlite bags $\left(6\right.$ plants $\left.\mathrm{m}^{-2}\right)$.

Six nutrient solutions with varied $\mathrm{NO}_{3}^{-}, \mathrm{H}_{2} \mathrm{PO}_{4}^{-}$and $\mathrm{SO}_{4}{ }^{2-}$ proportions were calculated following a $\{3,2\}$ simplex lattice design based on Cornell (1990) (Table 1), maintaining a total ionic concentration of $30.4 \mathrm{meq} \mathrm{L}^{-1}$. The cations of the nutrient solution were: $5 \mathrm{mmol} \mathrm{K} \mathrm{L}^{-1}, 4 \mathrm{mmol} \mathrm{Ca}{ }^{2+} \mathrm{L}^{-1}, 1.1 \mathrm{mmol} \mathrm{Mg}^{2+} \mathrm{L}^{-1}$.

The marketable yield, number of fruits and average fruit weight were recorded for total production. Every week tipburn incidence was evaluated by the leaf number with tipburn and the percentage of the leaf area with necrotic tissues, classifying them on the basis of the degree of tipburn in such a way that degree 0 was equivalent to total absence; degree 1, slight disorder; degree 2, intermediate case of tipburn and finally, degree 3 corresponded to a highly intense or severe tipburn. With these parameters, the average 
tipburn index (ATI) was calculated as the sum of $\mathrm{D}_{\mathrm{TBI}}{ }^{*} \mathrm{n}_{\mathrm{i}}$, where $\mathrm{D}_{\mathrm{TB}}$ is the degree of tipburn ( $i=1,2$ or 3 ) and $n_{i}$ was the number of leaves affected by degree $i$.

The significance of the differences was assessed by analyzing the variance. The effect of the main factors (cultivar and solution) and their interaction was partitioned. A multiple regression analysis was done. The response model was: $f(x): \beta_{1} N+\beta_{2} P+\beta_{3} S$ $+\beta_{4} \mathrm{NP}+\beta_{5} \mathrm{NS}+\beta_{6} \mathrm{PS}$, where $\mathrm{N}, \mathrm{P}, \mathrm{S}$ are the proportions of $\mathrm{NO}_{3}^{-}, \mathrm{H}_{2} \mathrm{PO}_{4}^{-}, \mathrm{SO}_{4}{ }^{2+}$ in the nutrient solution, NP, NS and PS, the interactions between the respective cation, and $\beta_{1}$ and $\beta_{6}$ the estimated parameters.

\section{RESULTS}

The marketable yield and fruit weight at the end of season was higher in 'Candonga' than in 'Camarosa' $(\mathrm{P}<0.05)$. No significant differences in fruit number per plant between cultivars were observed. The lowest levels of tipburn incidence were obtained in 'Candonga' plants $(\mathrm{P}<0.05)$. The statistical analysis did not reveal a significant effect of nutrient solution on the productive parameters studied. Nevertheless, the mathematical models for fruit yield were significant $(\mathrm{P}<0.01)$ and had high values of $\mathrm{R}^{2}$ (Fig. 1). The estimated lowest fruit yield appeared with high proportions of $\mathrm{SO}_{4}{ }^{2-}$ combined with low proportions of $\mathrm{NO}_{3}{ }^{-}$and $\mathrm{H}_{2} \mathrm{PO}_{4}{ }^{-}$, or with low proportions of $\mathrm{SO}_{4}{ }^{2-}$ combined with intermediate levels of $\mathrm{NO}_{3}{ }_{3}^{-}$and $\mathrm{H}_{2} \mathrm{PO}_{4}{ }^{-}$. The estimated lowest fruit weight appeared with low proportions of $\mathrm{NO}_{3}{ }^{-}$combined with intermediate proportions of $\mathrm{H}_{2} \mathrm{PO}_{4}{ }^{-}$ and $\mathrm{SO}_{4}{ }^{2-}$ (Fig. 1). The nutrient solution had a significant influence $(\mathrm{P}<0.05)$ on leaves with tipburn and ATI. At the end of the season, the percentage of leaves with tipburn and ATI was higher with the S6 solution, while for plants irrigated with S3, the nutrient solution with high sulphates proportions gave the lowest values for tipburn parameters (Table 2). Mathematical models indicated that greater incidences appeared with solutions with intermediate to low levels of $\mathrm{NO}_{3}{ }^{-}$together with high proportions of $\mathrm{H}_{2} \mathrm{PO}_{4}^{-}$. In contrast, expected values for ATI were lower in nutrient solutions with low sulphate proportions (Fig. 1).

\section{DISCUSSION}

Although we have not found differences in yields among the nutrient solutions assayed, the mathematical models were significant. This could have been due to the low differences in the yields observed among solutions. The incidence of tipburn in strawberry leaves could be promoted by a fast growth in plants (Saure, 1998; Ferrer et al., 2006). A high incidence of tipburn in leaves could also be caused by the nitrate supply that stimulates plant growth (Brumm and Shenk, 1993). Considering the nitrate levels in this experiment, we have found that the highest number of leaves with tipburn is achieved with nutrient solutions with low proportions of nitrates, which does not agree with the results cited before. However, it has to be taken into account that differences in nitrate levels have not been too high, varying only between 12.8 and $9.0 \mathrm{mmol} \mathrm{L} \mathrm{L}^{-1}$, and that differences would not be great enough to identify differences in plant growth or tipburn incidence. A high tipburn incidence in leaves was found when plants were fertigated with intermediate to high levels of phosphorus in the nutrient solution. Mason and Guttridge (1975) did not find any relation between phosphorus levels and tipburn incidence in strawberry, but it is in agreement with the results reported for strawberry by Ferrer et al. (2006). This adverse effect of high concentrations of $\mathrm{H}_{2} \mathrm{PO}_{4}^{-}$on this disorder could be related with the low calcium content in tissues when $\mathrm{H}_{2} \mathrm{PO}_{4}{ }^{-}$is at high concentrations.

In conclusion, within the factor space tested in this experiment, the use of nutrient solutions rich in nitrates and low in phosphates and sulphates should then be recommended, since they combined acceptable estimated values for commercial productions and fruit weight together with a relatively low tipburn incidence.

\section{ACKNOWLEDGEMENTS}

The authors acknowledge financial support by the "Ministerio de Educación y Tecnología'-FEDER, through the research project AGL2004-04365/AGR as well as the 
linguistic assistance of Debra Westall.

\section{Literature Cited}

Brumm, I. and Shenck, M. 1993. Influence of nitrogen supply on the occurrence of calcium deficiency in field grown lettuce. Acta Hort. 339:125-136.

Cornell, J.A. 1990. Experiments with mixtures. Design models and the analysis of mixture data. Wiley, New York.

Ferrer, M., San Bautista, A., Pascual, B., Maroto, J.V. and López-Galarza, S. 2006. Influencia de la composición aniónica de la solución nutritiva y de la tasa de crecimiento sobre la incidencia de tipburn en cultivo sin suelo de fresón. Actas de Horticultura 46:66-73.

López-Galarza, S., Escrivá, E., San Bautista, A., Pascual, B. and Maroto, J.V. 2003. Effects of cation composition of the nutrient solution on tipburn incidence in strawberry (Fragaria $\times$ ananassa Duch.) soilless cultivation. Acta Hort. 614(2):585589.

Mason, G.F. and Guttridge, C.G. 1974. The role of calcium, boron and some divalent ions in leaf tipburn of strawberry. Scientia Horticulturae 2:299-308.

Mason, G.F. and Guttridge, C.G. 1975. The influence of relative humidity and nutrition on leaf tipburn of strawberry. Scientia Horticulturae 3:339-349.

Saure, M.C. 1998. Causes of tipburn disorder in leaves of vegetables. Scientia Horticulturae 76:131-147.

\section{$\underline{\text { Tables }}$}

Table 1. The $\mathrm{NO}_{3}{ }^{-}, \mathrm{H}_{2} \mathrm{PO}_{4}{ }^{-}$and $\mathrm{SO}_{4}{ }^{2-}$ proportions and concentrations in the six nutrient solutions, for a total ionic concentration of $30.4 \mathrm{meq} \mathrm{L}^{-1}$.

\begin{tabular}{lrrcccc}
\hline Nutrient & \multicolumn{2}{c}{$\mathrm{NO}_{3}{ }^{-}$} & \multicolumn{2}{c}{$\mathrm{H}_{2} \mathrm{PO}_{4}{ }^{-}$} & \multicolumn{2}{c}{$\mathrm{SO}_{4}{ }^{2-}$} \\
\cline { 2 - 7 } solution & $\mathrm{mmol} \mathrm{L}^{-1}$ & $(\%)$ & $\mathrm{mmol} \mathrm{L}^{-1}$ & $(\%)$ & $\mathrm{mmol} \mathrm{L}^{-1}$ & $(\%)$ \\
\hline S1 & 12.80 & 84.2 & 0.90 & 5.90 & 0.75 & 9.90 \\
S2 & 9.00 & 59.2 & 4.70 & 30.9 & 0.75 & 9.90 \\
S3 & 9.00 & 59.2 & 0.90 & 5.90 & 2.65 & 34.9 \\
S4 & 10.90 & 71.7 & 2.80 & 18.4 & 0.75 & 9.90 \\
S5 & 10.90 & 71.7 & 0.90 & 5.90 & 1.70 & 22.4 \\
S6 & 9.00 & 59.2 & 2.80 & 18.4 & 1.70 & 22.4 \\
\hline
\end{tabular}


Table 2. Productive parameters at the end of season for each of the nutrient solutions (Si).

Different letters in columns correspond to significant differences (LSD, $\mathrm{P}<0.05$ ).

\begin{tabular}{|c|c|c|c|c|c|}
\hline Year and solution & $\begin{array}{l}\text { Fruit yield } \\
\text { (g plant }^{-1} \text { ) }\end{array}$ & $\begin{array}{c}\text { Fruit number } \\
\left(\mathrm{n}^{\mathrm{o}} \text { plant }^{-1}\right)\end{array}$ & $\begin{array}{c}\text { Fruit weight } \\
\quad\left(\mathrm{g} \text { fruit }^{-1}\right)\end{array}$ & $\begin{array}{l}\text { Leaves } \\
\text { TB }(\%)\end{array}$ & ATI \\
\hline \multicolumn{6}{|c|}{ 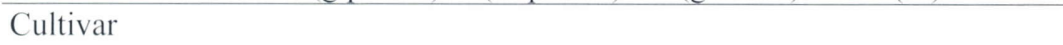 } \\
\hline 'Camarosa' & $420.9 \mathrm{~b}$ & 33.9 & $12.4 \mathrm{a}$ & $11.8 \mathrm{a}$ & $14.2 \mathrm{a}$ \\
\hline 'Candonga' & $457.7 \mathrm{a}$ & 33.3 & $13.7 \mathrm{~b}$ & $2.7 \mathrm{~b}$ & $2.2 \mathrm{~b}$ \\
\hline \multicolumn{6}{|l|}{ Solution } \\
\hline S1 & 441.7 & 33.3 & 13.3 & $7.2 \mathrm{~b}$ & $8.8 \mathrm{ab}$ \\
\hline $\mathrm{S} 2$ & 475.8 & 35.8 & 13.3 & $7.4 \mathrm{~b}$ & $9.7 \mathrm{ab}$ \\
\hline $\mathrm{S} 3$ & 412.4 & 31.7 & 13.1 & $3.8 \mathrm{c}$ & $3.2 \mathrm{~b}$ \\
\hline S4 & 415.5 & 32.1 & 13.0 & $6.4 \mathrm{~b}$ & $6.4 \mathrm{bc}$ \\
\hline S5 & 452.0 & 34.3 & 13.2 & $8.8 \mathrm{ab}$ & $9.2 \mathrm{ab}$ \\
\hline S6 & 438.6 & 34.5 & 12.7 & $9.9 \mathrm{a}$ & $11.8 \mathrm{a}$ \\
\hline
\end{tabular}

\section{Figures}

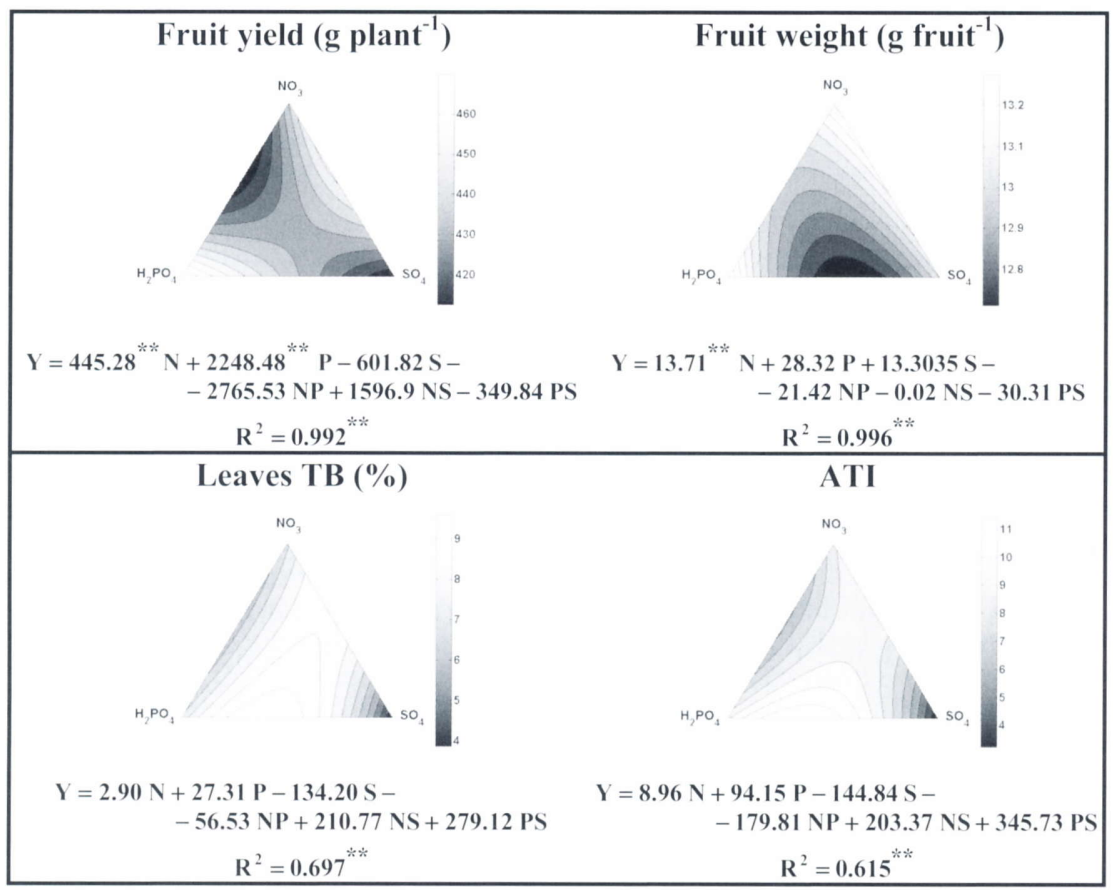

Fig. 1. Contour plots of the tested factor space, equation, regression coefficient and significance level of the model for the estimated influence of the anion proportion in nutrient solution on fruit yield, fruit weight, tipburn incidence, expressed as the percentage of leaves affected by tipburn and the average tipburn index (ATI), considering data for the whole season on average for the two cultivars. 

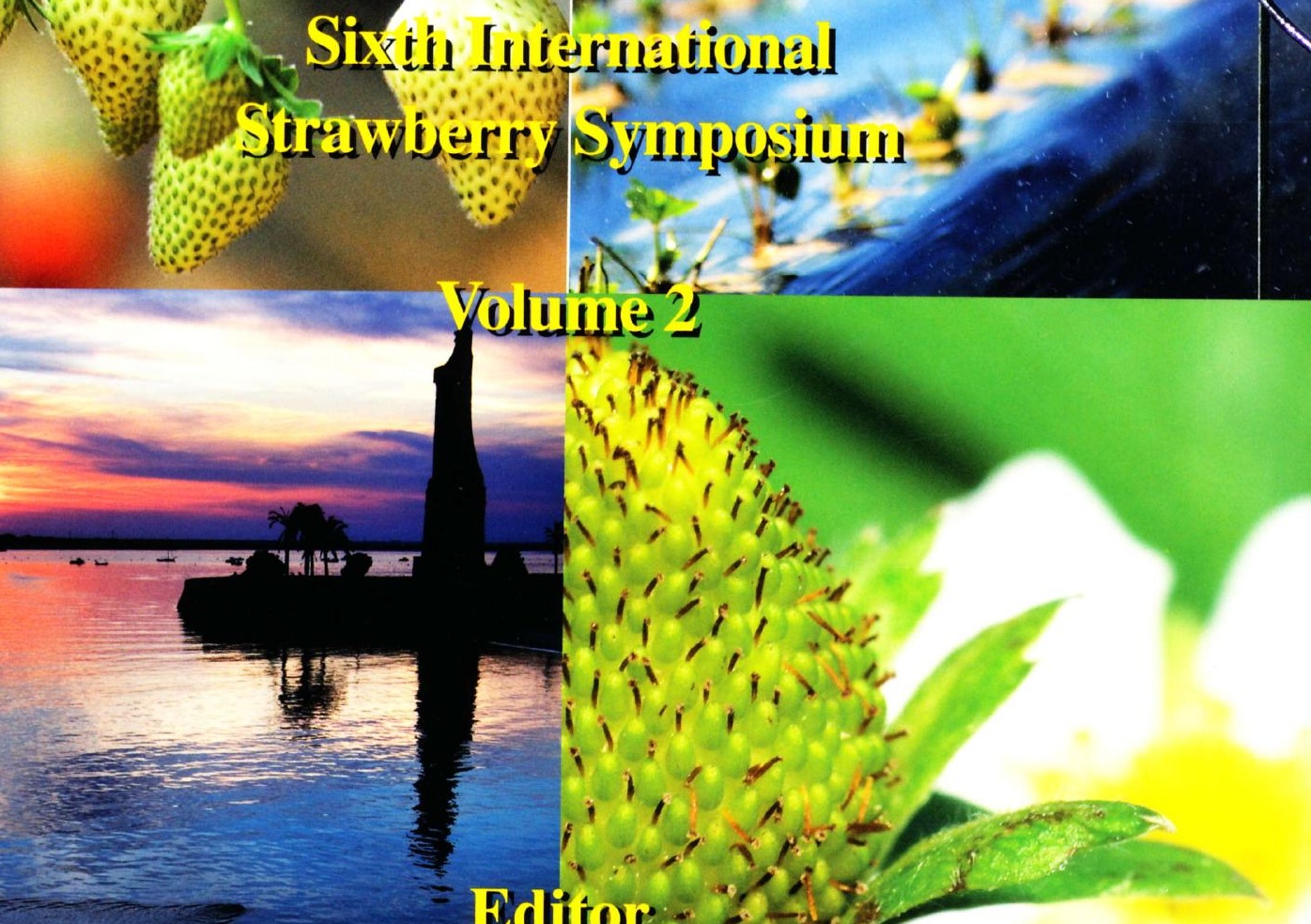

\section{J. López-Medina} 198

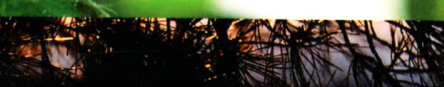

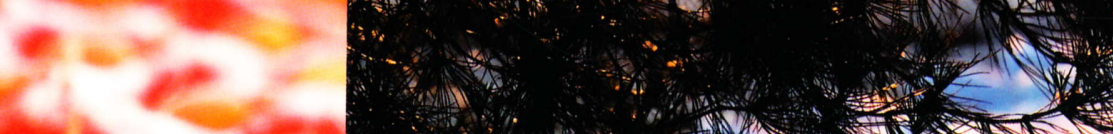
(1) 120.040 